This is a pre-print of an article published in International Review of Education. The final authenticated version is available online at: $\mathrm{https}: / /$ doi.org/10.1007/s11159-017-9685-7

\title{
Promoting community socio-ecological sustainability through technology: A case study from Chile
}

\author{
Claudio Aguayo ${ }^{1}$ \& Chris Eames ${ }^{2}$
}

\begin{abstract}
The importance of community learning in effecting social change towards ecological sustainability has been recognised for some time. More recently, the use of Information and Communication Technology (ICT) tools to promote socio-ecological sustainability has been shown to have potential in community education for sustainable development (ESD). The effective design and use of technology for community learning implies an understanding of a range of cross-dimensional factors including: socio-cultural characteristics and needs of the target audience; considerations of available and culturally responsive types of technology; and non-formal pedagogical ESD strategies for community empowerment. In addition, both technology itself and social communities are dynamically evolving and complex entities. This article presents a case study which evaluated the potential of ICT for promoting ecological literacy and action competence amongst community members in southern Chile. The case study addressed the ecological deterioration of a lake, which is having deep social, economic, recreational and cultural implications locally. The authors' research involved developing a theoretical framework for the design, implementation and use of ICT for community learning for sustainability. The framework was based on key ideas from ESD, ICT and community education, and was underpinned by a systems thinking approach to account for the dynamism and complexity of such settings. Activity theory provided a frame to address overarching sociocultural elements when using technology as a mediating tool for community learning. The authors' findings suggest that the use of an ICT tool, such as a website, can enhance ecological literacy in relation to a local socio-ecological issue.
\end{abstract}

Keywords: community education; ICT; systems thinking; socio-ecological sustainability; activity theory; transformative learning.

\footnotetext{
${ }^{1}$ Centre for Learning and Teaching, Auckland University of Technology, Auckland, New Zealand. Corresponding Author: caguayo@aut.ac.nz

${ }^{2}$ Faculty of Education, University of Waikato, Hamilton, New Zealand.
} 


\section{Introduction}

In this case study, we describe how a framework for promoting community socio-ecological sustainability was designed, implemented and evaluated in a community in southern Chile. The context was a lake in ecological decline, which was threatening wildlife and amenity values and causing concern to the local community. We postulated that developing the action competence (Jensen \& Schnack, 1997) of community members to address such an issue might be effectively achieved using information and communication technology (ICT). This thesis was underpinned by the dispersed nature of the local community, the high level of internet connectivity in the region and the affordances of ICT in promoting learning.

In the field of ICT, the term affordance is used in the context of the possibilities that technology can offer to users (Wallace, 2004). An affordance not only depends on what technology can offer to users, but also on the possible actions that users can carry out with such technology (Webb, 2005). Therefore, the affordance exists in the domain of the interaction between ICT and users. This calls for great emphasis on the understanding of users' characteristics and needs in order to design meaningful ICT-based affordances (Dohn, 2009; Webb, 2005; Woo, 2009).

We proposed a systems thinking approach to engage these affordances of ICT, which drew on the socio-cultural characteristics and needs of the local community, combined with a systemic approach to understanding and acting (Capra, 2005; Orr, 2014) upon the socio-ecological issue of the lake. This approach could develop ecological literacy by considering knowledge, values and actions in a holistic manner, in order to address the environmental, social, cultural, economic, and recreational implications of the issue. We theorised that the interaction of ICT tools with the socio-ecological needs of the local community could empower the members towards transformative change for sustainable development in the region.

\section{Background}

ESD is a mechanism for addressing socio-ecological sustainability issues. Key learning approaches within ESD are the development of ecological literacy (Orr, 1992), critical thinking (Huckle, 1993) and action competence (Jensen \& Schnack, 1997). Socially critical education and socially critical skills, or "the art of critical thinking" (Orr, 2004, p. xii), are seen as essential to effectively achieve the realization of sustainable living (Hofreiter, Monroe, \& Stein, 2007; Huckle, 1991; Huckle \& Sterling, 1996; Nicolaou et al., 2009; Tilbury, 1995). This approach coupled with critically informed and conscious action-taking targeted at the root cause of problems creates competence to bring about change (Jensen, 2002; Jensen and Schnack, 1997). 
These considerations indicate that ESD must go beyond raising awareness about environmental issues in addressing sustainability challenges (Kollmuss and Agyeman, 2002; Tilbury \& Wortman, 2008), and consider the environmental, social and political context of causes and consequences in order to achieve transformative change towards ecological sustainability (Fien \& Tilbury, 2002; Räthzel and Uzzell, 2009; Sterling, 2001). This goal can be conceived as ecological literacy, a process of understanding the underlying ecological principles of how people relate to each other and to natural systems, and to live sustainably (Capra, 2005; Orr, 1992). To be a literate person in a sustainable-living society requires a comprehension of wholesystem knowledge, or to understand how things are connected and interrelated (Armstrong, 2005; Barlow \& Stone, 2005; Capra, 2005; Orr, 2004; Sterling, 2001).

This systems thinking in ESD includes both application of systems thinking concepts in educational settings, and systems thinking perspectives for ESD. Applying systems thinking in community learning requires consideration of the learning context as a multidimensional complex entity. This calls for emphasis on the interaction between learning actors, the creation and nurturing of educational systems, and regarding educational systems as facilitators of learning (Davis \& Sumara, 2005; Jorg, 2000; Morrison, 2002; Sterling, 2005). Systems thinking perspectives for ESD involve promoting systems thinking, critical thinking, and/or development of the affective dimension in learning (Aguayo, 2015).

The importance of community learning for ESD has been recognised for some time (e.g. UNCED, 1992) to engender social change towards ecological sustainability (Tilbury \& Wortman, 2008; Zachariou \& Symeou, 2008). Learning in communities is characterised by social interaction (Capra, 2005; Krasny \& Roth, 2010), by being life-long, having relevance to the community and involving active participation (Brookfield, 1983; McConnell, 1997; Thompson, 2002; Tight, 2002). It is principally self-directed, or free-choice, and governed by an individual's learning needs and motivations (Brookfield, 1986; Chobot \& Chobot, 1990; Falk \& Dierking, 2002). In addition, learners in communities generally have diverse cognitive, intellectual and experiential backgrounds, dictating a need to offer a wide range of learning opportunities, including variety in intensity and sophistication (Brookfield, 1986; Chobot \& Chobot, 1990; Galbraith, 1990; Menzel \& Bögeholz, 2008).

We postulate that Information and Communication Technology (ICT) could promote community ESD by enhancing the understanding of sustainability issues, and by promoting community members' active participation towards sustainable development (Nicolaou et al., 2009; Phelps et al., 2008). Technology-enhanced non-formal ESD at the community level can contribute to making the links between ideas and concepts (i.e. understanding) with participative and action 
skills (Nomura, 2004; Thompson, 2002). Therefore, the use of ICT appears to be an inexpensive and effective way to engage social change for sustainability at the community level, and as a significant medium for the provision of community education for sustainability (Phelps et al., 2008; UNESCO, 2003; Vrasidas et al., 2007).

According to McNair (2006), as technology-enhanced educational settings are more likely to deal with individuals and their community's everyday problems and issues, the kind of learning that occurs tends to be more transformative than transmissive. Nonetheless, Selwyn (2006) points out that, although transformative learning "may be desirable, it is not dependent on the use of ICT or even necessarily encouraged by it" (p. 27), but rather on the social and cultural context, and both the attitudes and perspectives of the learner.

Common forms of ICT include the Internet and websites. Owston (1997) identified advantages of these as a learning mode that appears to be appealing to learners, their flexible learning possibilities (i.e. affordances), enabling new kinds of learning. The use of websites for online learning is commonly viewed in terms of the possibility of interconnectedness between learners, the independency of physical boundaries and time restraints compared to traditional forms of education, and the easier and quicker access to information (Owston, 1997; Wallace, 2004; Windschitl, 1998). Website learning affordances include graphical and multimedia aspects, the simplified access to information and databases, interactional features such as Web 2.0 and social media, and the constant growth of new learning technologies, digital tools and dynamic softwares (Becta, 2008; Clark et al., 2009; Fauville et al., 2014; Pachler \& Daly, 2009; Somekh, 2007).

On the other hand, barriers and constraints for the use of ICT and Internet websites for learning are that reliable ICT infrastructure is needed, which includes in this case reliability of computers, Internet connectivity and Internet-related software, and Internet-related skills on the part of users (i.e. ICT literacy), which will determine the degree of interaction between the computer and users (Becta, 2008; OECD, 2006; Pont \& Sweet, 2006; Wallace, 2004; Windschitl, 1998). As noted above, the affordances that a particular user will be in a position to engage in depends on the capacity to engage such affordances, for which Internet-related skills are needed (Dohn, 2009; Webb, 2005; Woo, 2009).

In the context of community-based education, one issue with ICT is that both the implementation and the use are regarded as complex processes. This is because these educational contexts deal with different and autonomous adults as community-members "whose choices of how and what to learn" are not dictated by formal educational institutions (McNair, 2006, p. 157); and because of the rate of innovation and development of ICT-based 
tools, and its interrelatedness with other dimensions such as social, cultural and infrastructure conditions (Cuban, 2001; Pachler, Bachmair \& Cook, 2010; Somekh, 2007). These concerns dictate that systems thinking, socio-cultural theories (e.g. cultural-historical activity theory), and qualitative perspectives are useful approaches for the investigation of the effects of the design, implementation and use of ICT in learning contexts (Aguayo, 2016; Kompf, 2005; McNair, 2006; Selwyn, 2006; Somekh, 2007; Webb, 2002).

In sum, fostering community socio-ecological sustainability through technology such as websites rests on three theoretical considerations: learning approaches and strategies that include development of cognitive, affective and action domains, relevance and learners' beliefs; education for sustainability (EfS) website tools and affordances such as connectivity, interaction and design for learning; and socio-cultural considerations for meaning, user-informed design and provision of networking opportunities. These theoretical considerations underpinned the development of a website for community learning in ESD in Chile, and this is described next.

\section{The Case Study: Online Community-based ESD at Lanalhue Lake in Chile}

The main research question driving this study was: Can the use of websites assist non-formal education for community understanding and action for sustainability issues in Chile? To address this question, the case study adopted a two stage approach: a theory-seeking stage, followed by a theory-testing stage (Basey, 1999). In the first stage a theoretical framework was developed from existing theory in ESD, community education and ICT. This was underpinned by systems thinking and complexity theory (Davis \& Sumara, 2005; Morrison, 2002; Sumara \& Davis, 1997) to account for the dynamism and unpredictable complexity of community-based non-formal educational settings (Aguayo \& Eames, 2016; Tilbury \& Wortman, 2008). This theory-seeking stage resulted in a framework for the development of education for sustainability websites targeted at non-formal community learning (Aguayo, 2014).

The second stage consisted of the evaluation and testing of this theoretical framework in a socio-ecological context in Chile. This stage employed Activity Theory (Engeström, 1987) as a meta-analytical framework to account for the socio-cultural factors and complexities within non-formal settings (Aguayo, 2016; Leadbetter, 2005). In this article we principally focus on this second stage, as a way to provide a critical account of the use of ICT for community learning for sustainability in non-formal environments. However, some key elements from the first stage will be discussed as necessary. 


\section{Theory-testing research design}

To address the research question, the EfS website Lanalhue Sustentable (i.e. http://www.lanalhuesustentable.cl) was developed to serve as a research instrument for data collection. The research design of this study consisted of three phases, each one involving particular methods of data collection. The first phase, the pre-design research phase, was aimed at achieving a deep understanding of the local, social, cultural, technological, educational and ecological characteristics and needs of the target community. This first phase was important in the effective and successful design, development, implementation and meaningful use of learning technologies for community learning in non-formal ESD (Aguayo, 2014). The second phase, the EfS website design phase, was informed by the theoretical framework developed during the first stage (theory-seeking stage) of the study, and shaped in a culturally-responsive way following findings from the first stage. The third phase, the evaluation phase, involved the collection of data based on the use of this EfS website by members of the target community of this study. Table 1 presents a brief description of the data collection methods associated with these three different phases.

Table 1. Data collection phases, methods, and associated issues related to the design, implementation and evaluation of the EfS website Lanalhue Sustentable.

\begin{tabular}{|c|c|c|c|c|}
\hline Research Phase & Objective & Methods & $\begin{array}{l}\text { Sample } \\
\qquad(\mathrm{n}) *\end{array}$ & Recruitment \\
\hline \multicolumn{5}{|c|}{ I. Pre-design research phase } \\
\hline $\begin{array}{l}\text { 1a. Determine target } \\
\text { community / } \\
\text { sustainability issue }\end{array}$ & $\begin{array}{l}\text { Analyse the general ESD, ICT and } \\
\text { sustainability contexts in Chile }\end{array}$ & $\begin{array}{l}\text { Interviews } \\
\text { Document analysis }\end{array}$ & 9 & $\begin{array}{l}\text { Invitation } \\
\text { Networking }\end{array}$ \\
\hline $\begin{array}{l}\text { 1b. Networking and } \\
\text { partnership }\end{array}$ & $\begin{array}{l}\text { Meeting with strategic individuals } \\
\text { and groups about the target } \\
\text { community }\end{array}$ & $\begin{array}{l}\text { Interviews } \\
\text { Document analysis }\end{array}$ & 9 & $\begin{array}{l}\text { Invitation } \\
\text { Networking }\end{array}$ \\
\hline $\begin{array}{l}\text { 1c. Understanding } \\
\text { target community's } \\
\text { contexts }\end{array}$ & $\begin{array}{l}\text { Input from key strategic individuals } \\
\text { and organizations regarding target } \\
\text { community }\end{array}$ & $\begin{array}{l}\text { Interviews } \\
\text { Document analysis } \\
\text { Observations }\end{array}$ & 11 & $\begin{array}{l}\text { Invitation } \\
\text { Networking }\end{array}$ \\
\hline $\begin{array}{l}1 \mathrm{~d} \text {. Assessment of } \\
\text { existing conceptions }\end{array}$ & $\begin{array}{l}\text { Survey of community members } \\
\text { regarding their existing sustainability } \\
\text { conceptions }\end{array}$ & Questionnaire & 19 & $\begin{array}{l}\text { Invitation } \\
\text { Public } \\
\text { advertisement }\end{array}$ \\
\hline
\end{tabular}




\begin{tabular}{|c|c|c|c|c|}
\hline $\begin{array}{l}\text { 1e. Websites } \\
\text { preferences }\end{array}$ & $\begin{array}{l}\text { Survey of community members } \\
\text { regarding preferences of website } \\
\text { affordances }\end{array}$ & $\begin{array}{l}\text { Interviews } \\
\text { Questionnaire }\end{array}$ & 19 & $\begin{array}{l}\text { Invitation } \\
\text { Public } \\
\text { advertisement }\end{array}$ \\
\hline $\begin{array}{l}\text { 1f. Understanding of } \\
\text { sustainability issues } \\
\text { at target community }\end{array}$ & $\begin{array}{l}\text { Input from key strategic individuals } \\
\text { and organizations regarding } \\
\text { sustainability issues }\end{array}$ & $\begin{array}{l}\text { Interviews } \\
\text { Document analysis } \\
\text { Observations }\end{array}$ & 11 & $\begin{array}{l}\text { Invitation } \\
\text { Networking }\end{array}$ \\
\hline \multicolumn{5}{|c|}{ II. EfS website design phase } \\
\hline $\begin{array}{l}\text { 2a. Design and } \\
\text { development of ESD } \\
\text { website }\end{array}$ & $\begin{array}{l}\text { Input from web design experts, web } \\
\text { design team, and local community } \\
\text { members }\end{array}$ & $\begin{array}{l}\text { Interviews } \\
\text { Observations }\end{array}$ & 5 & $\begin{array}{l}\text { Invitation } \\
\text { Networking }\end{array}$ \\
\hline \multicolumn{5}{|c|}{ III. Evaluation phase } \\
\hline $\begin{array}{l}\text { 3a. Pre-intervention } \\
\text { questionnaire }\end{array}$ & $\begin{array}{l}\text { Assessment of demographics, ICT } \\
\text { skills, and knowledge about local } \\
\text { sustainability issues }\end{array}$ & Questionnaire & 24 & $\begin{array}{l}\text { Invitation } \\
\text { Networking }\end{array}$ \\
\hline $\begin{array}{l}\text { 3b. Intervention: use } \\
\text { of the EfS website by } \\
\text { participants }\end{array}$ & $\begin{array}{l}\text { Quantitative data collection on the } \\
\text { use of the EfS website }\end{array}$ & Google Analytics & 24 & $\begin{array}{l}\text { Invitation } \\
\text { Networking }\end{array}$ \\
\hline $\begin{array}{l}\text { 3c. Post-intervention } \\
\text { interview }\end{array}$ & $\begin{array}{l}\text { Assessment of the perceptions of the } \\
\text { website, change in understanding, } \\
\text { and motivation to take action }\end{array}$ & Interview & 24 & $\begin{array}{l}\text { Invitation } \\
\text { Networking }\end{array}$ \\
\hline 3d. Follow-up survey & $\begin{array}{l}\text { Evaluation of change in } \\
\text { understanding, actions carried out, } \\
\text { and adoption of sustainable living } \\
\text { principles based on website revisits } \\
\text { during follow-up period }\end{array}$ & Online survey & 18 & $\begin{array}{l}\text { Invitation } \\
\text { Networking }\end{array}$ \\
\hline
\end{tabular}

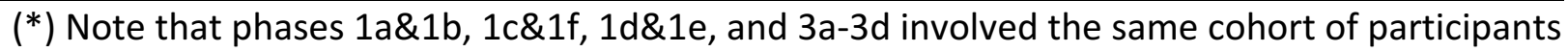
respectively.

Data analysis was carried out based on the Activity Theory framework represented in Figure 1, which attempted to account for the socio-cultural, ecological, technological and educational particularities of the target community. This involves the identification and description of the 
overarching elements constituting the activity system defined by the framework and the resultant ESD website. These elements include the sociocultural and historical background of the target community, the affordances provided by the ESD website, the division of labor of the activity system, and the rules determining the activity system (Aguayo, 2016; Engeström, 1987, 2001). Within this framework, data was analysed for its deductive coherence with the theoretical positions described above, and inductive emergent properties. Quantitative data (from the questionnaires and Google Analytics) was processed using SPSS software to produce descriptive statistics. Qualitative data (from the observations and interviews) was processed following La Pelle's (2004) qualitative data analysis method. This method is based on the use of Microsoft Word tables and associated data management tools for the organization, coding (descriptive and analytical inference), interpretation and presentation of data.

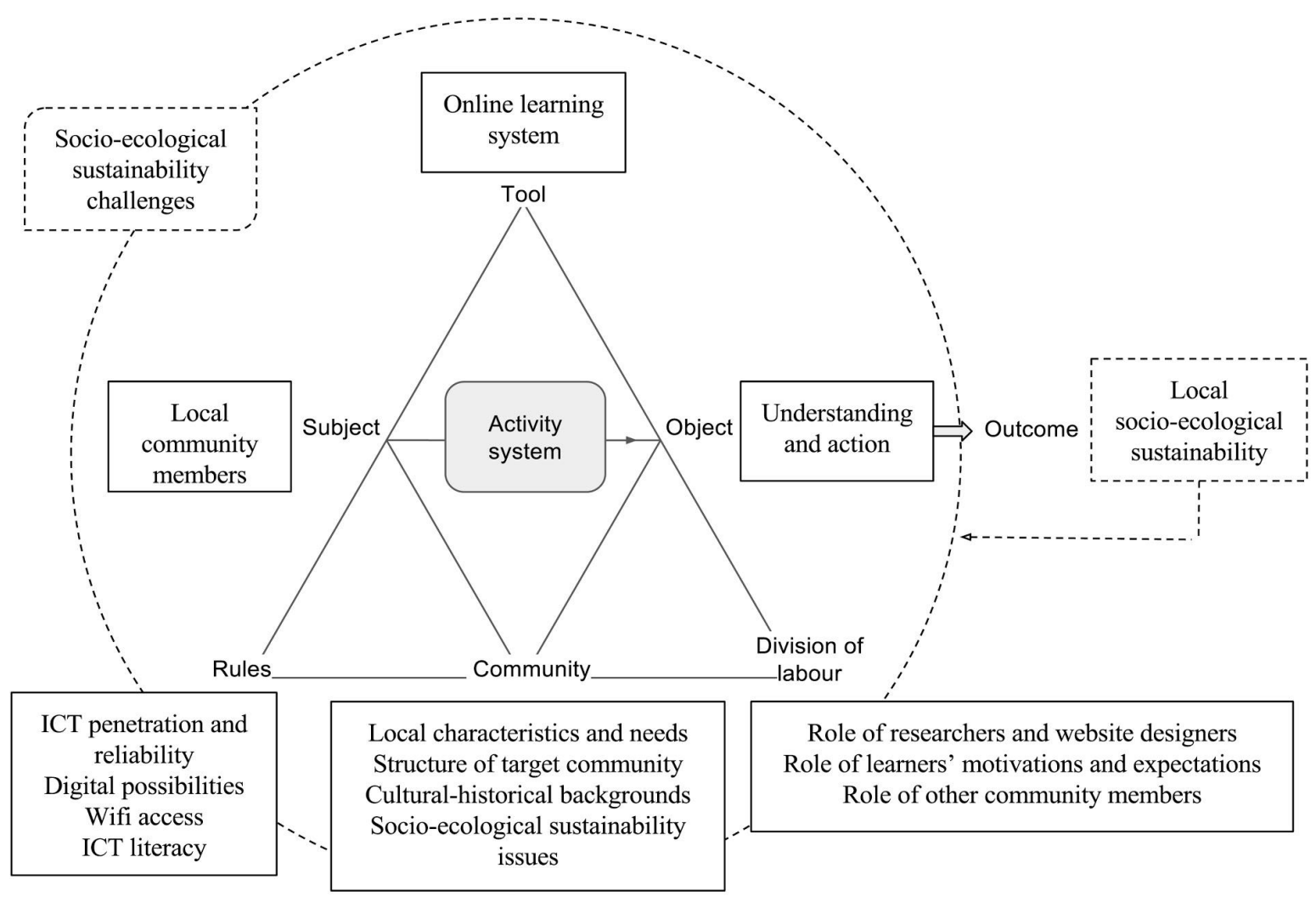

Figure 1. Activity system in the context of Lanalhue Lake (source: adapted from Aguayo, 2016).

In coming sections we expand on each the research phases from Table 1 starting with the contextualisation of the research in terms of describing the target community: The Lanalhue Lake in Chile. 
Target community: The Lanalhue Lake in Chile

The Lanalhue Lake in Chile, situated approximately $180 \mathrm{~km}$ South of the main city of Concepción in the Bio-Bio Region, and $15 \mathrm{~km}$ from the coast of the Pacific Ocean, is one of the few coastal lakes of Chile. It is part of the Nahuelbuta Range (Figure 2b), considered a biodiversity hot spot at the global level due to its high degree of endemism (Myers, 2005; WWF, 1999). The area of the lake covers 3,190 hectares, and is nurtured principally by fluvial waters, in contrast to the majority of Chilean lakes that are nurtured by glaciers and snow waters from the Andes. The lake presents a very slow renewal rate of its waters due to its hydrographical, and local climate characteristics (i.e. approx $1400 \mathrm{~mm}$ of rain per year, principally during winter and spring) (Parra et al., 2003). This seasonal rainfall factor makes the water level of the lake fluctuate between \pm 3 to 5 meters, with some associated ecological consequences, for example, washing away cattle land during winter time contributing to the increase of organic nutrients in the lake.

The Lanalhue Lake is close to two major towns: Contulmo, near the South-East shores of the lake, with approximately 1500 inhabitants (i.e. \pm 6000 during summer); and Cañete, $18 \mathrm{~km}$ North of the lake, with approximately 22,000 inhabitants (see Figure 2c). There are also three other smaller populated areas by the shores of the lake: Peleco (Cañete district), and Lanalhue and Elicura (Contulmo district); as well as some areas with a growing presence of holiday cottages and residential houses along the shores of the lake. In general terms, this region of Chile is considered socio-economically as highly vulnerable due to its high levels of poverty and low levels of development (MIDEPLAN, 2010). The Lanalhue Lake area is also a Mapuche area (Chilean indigenous inhabitants), with a high number of Mapuches still present in the area, and some Mapuche communities within the catchment of the lake and surrounding valleys, which makes this area unique from a social and cultural point of view.

In terms of the economic dimension, the area is dominated by the forestry industry, with large pine (Pinus radiata) and eucalyptus (Eucalyptus sp.) plantations across the Nahuelbuta Range (Pauchard, Smith-Ramírez \& Ortiz, 2006; Smith-Ramírez, 2004; WWF, 1999). The forestry industry started explosively during the mid 1970s, and today very large forestry plantations can be seen within the catchment of the Lanalhue Lake (Comisión Lago Lanalhue, 2007). Other major economic activities present in the area are related to agriculture and tourism industries, with an evident increase of holiday cottages and tourism facilities and services in some sectors of the lake in the past fifteen years (Aguayo, 2014; Etchepare \& Furet, 2008).

The contemporary anthropogenic use of land within the catchment of the lake has contributed to a significant alteration of the original ecological conditions of the Lanalhue Lake, including water quality deterioration, increase in organic nutrients and sedimentation, and the 
consequent accelerated process of eutrophication of the lake (Etchepare \& Furet, 2008; Pauchard et al., 2006). The most apparent environmental and sustainability issue at the local level is related to the increase of nutrients in the lake, and the consequent proliferation of the Egeria densa aquatic plant (local common name "luchecillo"), originally from Brazil and considered an invasive plant and a eutrophication indicator (Centro Regional de Estudios Ambientales [CREA], 2009; Lanalhue Sustentable, 2011).
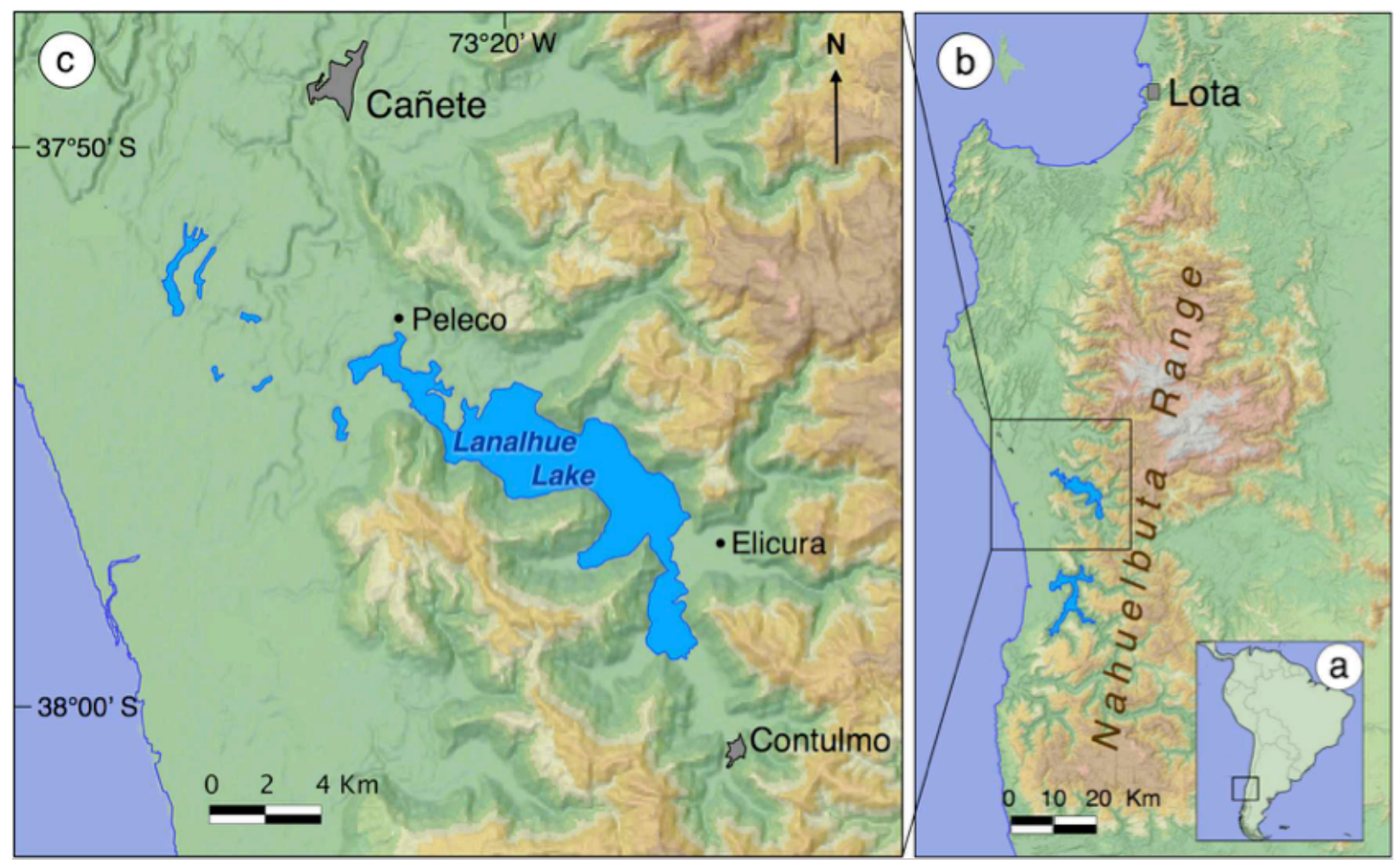

Figure 2. Geographical location of the Lanalhue Lake in Chile. Diagram (a) shows the location of the lake within the South-American continent. Diagram (b) shows the location of the lake in the context of the Nahuelbuta Range in Chile; and diagram (c) in the context of the local communities present in the area of the Lanalhue Lake. (Source: Aguayo, 2014)

Besides the ecological dimension and related issues, this burst in presence of luchecillo has created problems within the tourism industry (an economic dimension), the recreational use of the lake by community members and visitors (a social dimension), and with the spiritual practices of local indigenous communities (spiritual and cultural dimensions) (Aguayo, 2014; Etchepare \& Furet, 2008; Lanalhue Sustentable, 2011), among others. All these factors may contribute directly or indirectly to the overall socio-ecological sustainability of the area, and many of them to the process of the accelerated eutrophication of the lake. 
Pre-design phase: Characteristics and needs of the target community

The pre-design research phase is probably one of the most critical phases in the successful integration of ICT for non-formal ESD (Aguayo, 2014). This involves achieving a deep understanding of the local, social, cultural, technological, and educational characteristics and needs of the target community. Learning technologies can be shaped to meet and fulfill people's characteristics and needs, therefore becoming locally relevant and culturally responsive (Aguayo, 2016). In this study such deep understanding of the local community was achieved through community-based ethnographic research. The researcher spent several months within the target community, embedding himself into the 'reality' of the local context and socio-ecological sustainability issues.

This process consisted of formally and informally interviewing and talking to local members of the community, always seeking input from different perspectives, stakeholders, and key community members. This process also included questionnaire surveys (ecological and ICT literacy, and website preferences), observations, and analysis of the local media addressing local sustainability issues, particularly those related to the socio-ecological sustainability of the Lanalhue Lake. However, since communities represent such a wide variety of people and stakeholders, it was not possible to access the views of all identified key members of the community, partly due to logistics and partly to lack of engagement. In part because of logistics and lack of time from the researchers, and in part due to lack of interest from some of the community members themselves. Funding for website development and finding common ground and language within the development team also presented challenges.

In sum, by spending time in the community and becoming part of it, it was possible to gain a deep understanding not only of the community, but also knowledge about the socio-ecological issue. Networking and establishing research partnerships facilitated the whole process (Aguayo \& Eames, 2016). Some key partners demonstrating evident commitment to the issue were invited to provide active input to the research, therefore gaining a sense of ownership towards the EfS website to be developed from the very beginning. Key partners were also invited to be part of the design phase of the website. Some of those partnerships are still in place more than five years after the field research.

\section{Design Phase: The EfS website Lanalhue Sustentable}

This phase consisted of setting up a website design and development team, which included one of the researchers, a graphic designer, a web developer, and some members of the local community acting as consultants and end-users. This design phase was based on the theoretical framework developed in the first stage of this research (theory-seeking stage), on data collected during the pre-design research phase, and on constant feedback loops with key community- 
based partners, including local members of the design team. After several months of design, development, testing and a final implementation, the EfS website Lanalhue Sustentable was released in February 2011. Figure 3 shows the homepage view of the website with an indication of the implementation of some of the theoretical considerations and design-based approaches informing the website.

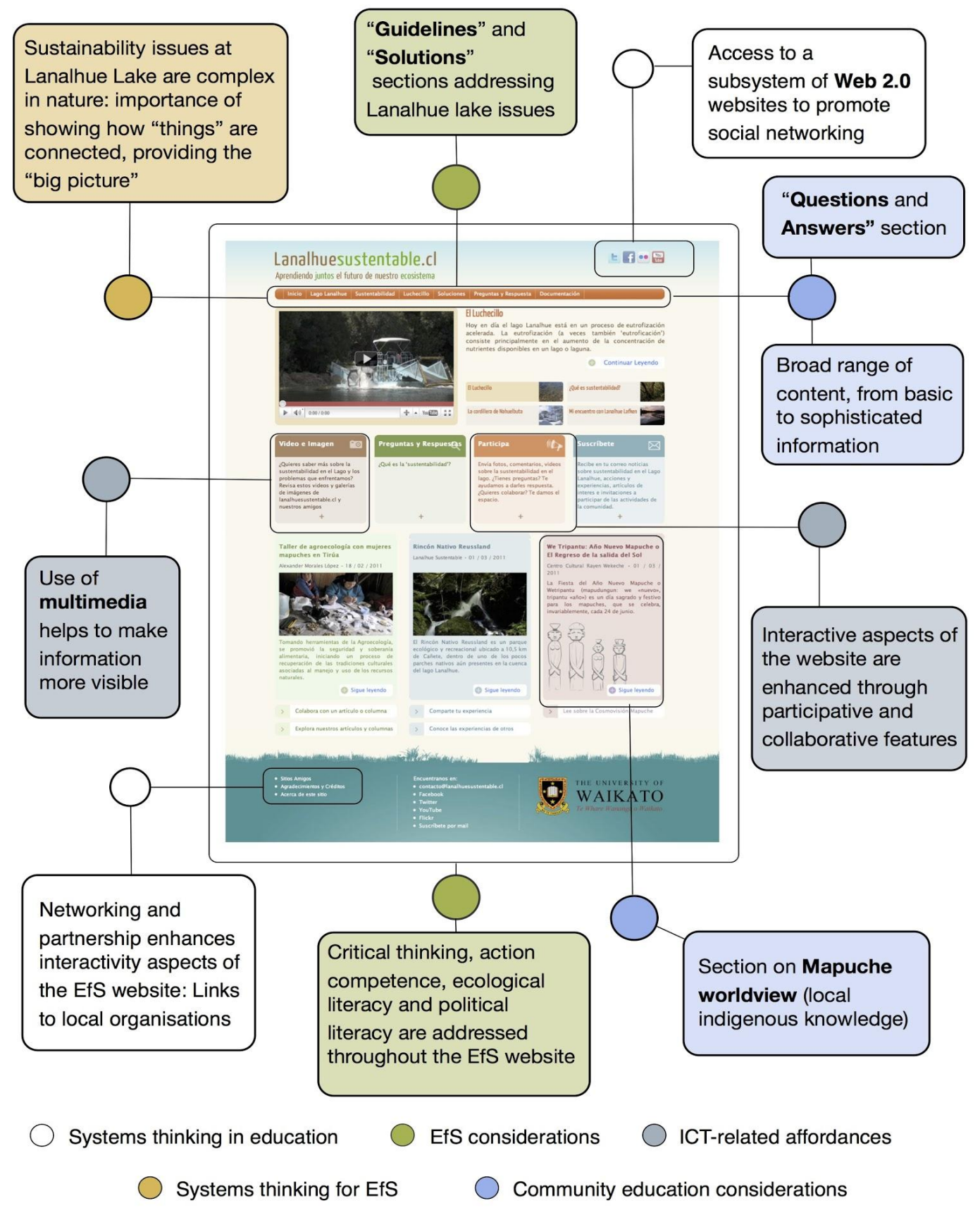

Figure 3. Organisational layout of the homepage of the website Lanalhue Sustentable [http://www. Lanalhuesustentable.cl]. 
This website was used as the research instrument to study the use and impact of ICT for nonformal community learning around the local socio-ecological sustainability issues affecting the local community. Details of this research phase are reported elsewhere (Aguayo, 2014; Aguayo \& Eames, in preparation). In the context of this case article, it is important to highlight here how epistemological and methodological approaches, derived from systems thinking and complexity theory in education combined with Activity Theory, were a fundamental part of it. Design principles promoted the emergence of non-formal and social learning, and distributed cognition through: interactivity, diversity, means for learners to affect each other, and a decentralised control structure (Aguayo, 2014; Davis \& Sumara, 2005).

One issue in the application of the theoretical framework here, in part due to the purpose of the website being a doctoral study, was a lack of consideration of how the website would be managed after the completion of the research. This issue calls not only for consideration of the long-term (financial) viability of technology-based learning systems, and how these can adapt to emerging technologies and affordances and still keep their meaningfulness, but also on ways to 'leave' the website in the hands of the local community for long-term management and updating over time.

Evaluation phase: Transformative learning and action-taking by community members

Twenty-four local community members participated in this evaluation phase. They were invited to freely interact with the EfS website for a period of time ranging between 10 to 25 minutes, depending on their time availability and motivation. This interaction with the website was preceded by a pre-intervention questionnaire assessing demographics, ICT and ecological literacy, and knowledge about local sustainability issues; and followed by a post-intervention interview assessing perceptions towards the website, change in understanding, and motivation to take action and adopt sustainable living principles. A final follow-up online questionnaire, five months after the intervention, assessed revisits to the website, change in understanding over time, and action taking and sustainable living based on post-intervention interactions with the EfS website.

Types of interaction with the website were evaluated using Google Analytics, helping to determine general patterns of interaction of participants with the EfS website. However, data gathering limitations only permitted this analysis at the cohort level. Pre-intervention levels of ecological literacy allowed the categorisation of participants into three different literacy typologies (low, medium and high level of ecological literacy). Assessment of change in understanding over time was based on the evaluation of the learning process reported by participants, interpreted from a naturalistic and social constructivist point of view, and based on an ecological literacy knowledge framework (Aguayo, 2014). Action taking and adoption of 
sustainable living principles were assessed through comparative analysis between reported motivations during the post-intervention interview, and reported action taking and adoption of sustainable living principles during the follow-up survey.

Findings indicated that the EfS website Lanalhue Sustentable promoted deep and transformative types of learning, locally-based ecological literacy, action taking, and adoption of sustainable living principles and practices amongst some of the participant community members. Details of the findings are reported elsewhere (Aguayo, 2014; Aguayo \& Eames, in preparation), and our purpose here is to focus on those findings that allow us to critique whether socio-ecological sustainability was enhanced through the use of technology.

Data from Google Analytics indicated that, as a cohort, participants tended to visit the web pages or page sections relating to the eutrophication of the lake more, with pages/sections on 'Lanalhue Lake', 'Sustainability', 'Luchecillo', 'Solutions' and 'Q\&As' sections the top five (out of 23 sections) being most visited during participants' first interactions with the website. When asked what they thought about the website during the post-intervention interview, 16/24 participants noted that the 'website deals with locally relevant and meaningful issues', and $10 / 24$ reported that the 'website has a clear message, is easy to understand, and is attractive'. This reflects the meaningfulness and engagement achieved through the design process. For example, Javiera (note that all reported names are pseudonyms) reported:

I think it is excellent! I think it is excellent because it deals with different issues that are related to the lake, and actors that are directly involved, like for example I saw the Mapuche issue, the topic about women that work on agriculture but within a conservation scope. So I think it is interesting, I couldn't check it more but I will definitely visit the website regularly.

Participants' general perceptions of the website indicated that at least three key theoretical considerations for the design of ESD websites were effective for their learning. These include the importance of clearly defining and addressing the social and cultural needs of the target community, the inclusion of relevant and meaningful knowledge to the target community (Aguayo, 2014; Thompson, 2002), and offering website users a range of meaningful affordances, including accessibility, navigability, and sophistication and clarity of message (Aguayo, 2014). While most users were very satisfied with the usability of the website, a teacher participant noted that it could "add some drawings for children, so the website can be used by all kinds of person, from adults to kids, to include some cartoons for the kids".

Indications of learning over time were seen by comparing ecological literacy data from the postintervention interview and the follow-up online survey. In particular, of fourteen participants 
who answered questions related to this aspect across both data collection phases: 10/14 indicated a better understanding towards local sustainability issues, 3/14 participants indicated the acquisition of systems thinking and ecological literacy towards local issues, and 2/14 participants were shown to have gained transformative understanding towards local issues in the follow up survey. One participant who indicated transformative understanding was Rafael, who over time presented a transformative change by clarifying myths regarding local issues, and by exhibiting critical thinking towards actions undertaken so far by local authorities:

I had never before heard the 'eutrophication' concept, and on the website it is very well explained. This took me to demystify people's diverse opinions regarding the lake, and to have a more critical view in regard to actions undertaken so far, like in the case of the luchecillo harvester machine. To have a management plan based on local scientific research is definitely needed.

In terms of change in understanding over general sustainability issues, of 12 participants who answered questions related to this aspect across both data collection phases: 4/12 participants reported a better understanding; 4/12 participants reported acquiring ecological literacy and systems thinking perspectives; and 4/12 participants indicated transformative understanding. Some of these changes in understanding were topic specific, such as a change in understanding in relation to local indigenous people, or to existing local initiatives. For example, Pamela noted the following:

Before knowing the website, personally you do not know what is going on in regard to what other people are doing for the environment, so my perception has changed when we say 'how come nobody does anything to help?' when you see the deterioration or death of something related to the environment; now I can say that there are people doing something, which motivates me to participate and be a positive part of it.

Perhaps not surprisingly, whilst there were 24 participants in the intervention exploring the website, by four months later only 18 were able to be re-engaged in the study for the follow up survey. We see this related to a lack of reinforcing activities as part of the website intervention, due to constraints of the study. When this study was designed in 2009, web 2.0 and social media affordances and spaces were still emerging, and in the particular context of the Lanalhue Lake pre-design research data indicated that it wasn't a relevant affordance to consider at the time to meet identified characteristics and needs of the local community around ICT. Therefore low priority was given to this. Although the website did have an associated Facebook Group which became quite active in terms of attracting followers (even until today), as there was no research design in place for this aspect, its potential use to promote reinforcement and meaningfulness over time was not properly addressed. Again, this is a key consideration for future experiences using technology for non-formal ESD: to consider long-term sustainability, 
and to embrace new technologies and affordances as they emerge (Aguayo, 2014; Aguayo et al., 2016).

In terms of action taking, and adoption of sustainable living principles and practices, data was analysed by comparing reported intentions and motivations from the post-intervention interview with data from the follow-up online survey. Four types of actions were identified: (1) 'website related actions', with 'told a friend about the website' and 'visited links shown on the Lanalhue Lake website' being the two most reported actions; (2) 'lake related actions' with 'visited the lake', 'thought about how you could help improve the lake's environment', and 'taken any other direct action to help improve the lake's environment' being the three most reported ones; (3) 'immediate environment actions' (referring to participants' immediate environment), with 'taken any direct action to help improve your immediate environment (e.g. at home)' being the most reported subtheme; and (4) 'other actions', with Romina being the only participant scoring here. Her reported action was to gain deeper knowledge and competence in ESD through self-driven learning.

Finally, regarding adoption of sustainable living principles and practices, 14 participants of 18 reported doing so, including recycling, water care, avoid littering, environmental case of Lanalhue Lake, enjoy nature, renewable energy and healthy food being some of them. This data is tentative, however, as it became clear the choice of an online survey for practical reasons limited insights from the data regarding actual action-taking and other data collections methods may have elicited a better picture. Another limitation was that the follow-up survey was carried out just four months after the intervention, again due to study constraints, and while this meant that thinking and motivation to act on the issue was possibly still fresh in participants' minds, it is a relatively short timeframe to see significant shifts in action other than at the individual level and mainly related to the issue being focused on.

\section{Discussion and Conclusion}

The case study presented here has provided evidence for the potential of ICT to enhance community ESD. The creation of a theoretical framework (the theory-seeking stage) connected learning theories from ICT and ESD through a systems thinking approach to inform the design, implementation and use of a website for community ESD. It sought to connect ecological and ICT experts through one non-formal educational system. Critical factors for the effective use of technology for community ESD were identified during this process.

First, the achievement of a deep understanding of the local characteristics and needs of the target community helped provide meaningful and culturally responsive learning experiences. 
Achieving this understanding was a time-consuming and detailed process, but provided confidence that the learning experiences to be designed would be relevant to participants. Drawing on the ecological features of Lanalhue Lake and its surroundings, the socio-economic interests of the local community and the culture of the indigenous Mapuche, a website was designed which integrated these dimensions. The website took a critical stance on the importance of the lake in a biodiverse region, the deterioration of the lake and its impact on local tourism, the influence on surrounding land-use, and the historical marginalisation of the Mapuche people in the district. The investment of time and planning in this systemic approach appeared to be effective in engaging participants deeply in the learning experience provided by the website, both for their initial visit and in eliciting further visits.

Second, the design phase created an EfS website which was useable by community members with a range of pre-existing ecological and ICT literacy levels. Involving local members of the community as part of the website design team as advisors and end users appeared to be important in maximising the potential for technology to enable effective learning experiences. In this context, technology-enhanced learning systems, such as the EfS website Lanalhue Sustentable, are seen as active facilitators of the learning process (Aguayo, 2014; Davis \& Sumara, 2005) by promoting interaction, structural coupling between learning actors, and the emergence of locally meaningful learning processes. We see this epistemological consideration as critical when designing technology-enhanced learning systems, and when shaping technology for community ESD within socio-cultural and socio- ecological sustainability-related contexts. In the case study presented here, this epistemological approach permitted us to deal with the unpredictable and complex nature of non-formal educational settings using learning technologies for the delivery of ESD goals. It illustrated how social learning approaches informed by multiple stakeholders could facilitate transformation (Wals, 2015).

Third, the evaluation phase indicated that technology-enhanced learning systems, in particular website tools and their potential uses, can promote knowledge development and critical thinking, attitudinal change and action-taking for socio- ecological sustainability; in other words, our expectation that ecological literacy could be enhanced (Capra, 2005) was confirmed. Adopting an activity theory approach to data gathering and analysis helped us on the one hand to understand the possibilities for facilitating social and distributed learning in the form of expansive learning at the individual level as well as the complexity of factors in this expansive learning system (Engeström, 2001). On the other hand, it also enabled us to recognise the limitations of a website. For example, the follow-up online survey we conducted four months after participants' initial visit to the website showed that, while knowledge may have been retained and even built on for those community members who had voluntarily revisited the website, the lack of post-learning experience reinforcement had led to less reported action on 
the issue than we had hoped for. This signals the need for more intense reinforcement (Ballantyne \& Packer, 2011) after such learning experiences; we posit that social media, had they been better developed at the time of the study, would have potentially enabled that reinforcement (Wals, 2015; Warner et al., 2014). In future interventions, this may more readily bring about the sort of transformative change within communities which is required for longterm effectiveness (Fien \& Tilbury, 2002; Räthzel \& Uzzell, 2009; Sterling, 2001).

We believe the educational design principles illustrated here are transferable to other community ESD settings. To build an evidence base for such transferability, the theoretical framework for the use of ICT for community ESD needs to be further enhanced, tested and applied within other contexts. Key requirements are a target community with access to learning technologies and some degree of ICT literacy, and an existing locally based socio-ecological sustainability issue demanding action. A critical consideration is the ever-evolving nature of learning technologies. In response, design teams can maximise learning potential by using the most appropriate technologies to meet local socio-cultural characteristics and needs, and by continually evaluating emerging technologies. Thus, there is also a need to research and understand the adaptive capacity of learning technologies over time, such as autopoietic (selfmaintaining) entities (Maturana \& Varela, 1980), and to consider their sustainability in order to remain locally meaningful and relevant within ever-changing dynamic social systems.

Finally, we acknowledge that technology use can isolate people from rather than engage them with their local places; however, our study suggests this is not a helpful dichotomy. Two realities of today's world are an increasing use of technology and an increasing physical and emotional disconnect with the local natural places which are so important to us ecosystemically. We therefore see the problem as the solution, and consider ways in which technology can re-connect people with nature, place and each other. However, this must be addressed in culturally responsive and values-based ways in order to promote positive types of technology use which are locally meaningful. This study has indicated that with purposeful design in the use of technology, this may be possible.

\section{References}

Aguayo, C. (2014). The use of education for sustainability websites for community education in Chile. Doctor of Philosophy (PhD) Thesis. University of Waikato, Hamilton, New Zealand. Retrieved from http://researchcommons.waikato.ac.nz/bitstream/handle/10289/8640/thesis.pdf?sequen ce=3\&isAllowed $=y$ 
Aguayo, C. (2015). Editorial - La cuestión ambiental: de la razón a las cosas del corazón. TED Tecné, Epistemes Y Didaxis, 38(2), 7-13. Retrieved from http://revistas.pedagogica.edu.co/index.php/TED/article/view/3702/3254

Aguayo, C. (2016). Activity theory and community education for sustainability: When systems meet reality. In D. Gedera \& J. Williams (Eds.), Activity Theory in Education: Research and practice (pp. 139-151). Rotterdam: Sense.

Aguayo, C., \& Eames, C. (2016). Community partnerships in sustainability education research. In R. McNae \& B. Cowie (Eds.), Realizing Innovative Partnerships in Educational Research. Sense Publishers. In Press.

Aguayo, C., Higgins, B., Field, E., Nicholls, J., Pudin, S., Tiu, S. A., Osborn, M., Hashemzadeh, F., Lubuulwa, K., Boulet, M., Christie, B. \& Mah, J. (2016). Perspectives from emerging researchers: what next in EE/SE research? Australian Journal of Environmental Education, 32(1), pp. 17-29.

Armstrong, J. (2005). En'owkin: Decision making as if the sustainability mattered. In M. Stone \& Z. Barlow (Eds.), Ecological literacy: Educating our children for a sustainable world (pp. 1117). San Francisco: Sierra Club Books.

Barlow, Z., \& Stone, M. (2005). Introduction. In M. Stone \& Z. Barlow (Eds.), Ecological literacy: Educating our children for a sustainable world (pp. 1-8). San Francisco: Sierra Club Books. Bassey, M. (1999). Case study research in educational settings. Buckingham: Open University Press.

Becta. (2008). Emerging technologies for learning (Vol. 3). Coventry: Becta.

Brookfield, S. (1983). Adult learners, adult education and the community. Milton Keynes: Open University Press.

Brookfield, S. (1986). Understanding and facilitating adult learning: A comprehensive analysis of principles and effective practices. Milton Keynes: Open University Press.

Capra, F. (2005). Speaking nature's language: Principles for sustainability. In M. Stone \& Z. Barlow (Eds.), Ecological literacy: Educating our children for a sustainable world (pp. 1829). San Francisco: Sierra Club Books.

Centro Regional de Estudios Ambientales (CREA). (2009). Evaluación rápida del estado trófico del lago Lanalhue. Concepción, Chile: Universidad Católica de la Santísima Concepción.

Chobot, M. C., \& Chobot, R. B. (1990). Museums as educational institutions. In M. W. Galbraith (Ed.), Education through community organizations (Vol. 47, pp. 55-62). San Francisco: Jossey-Bass.

Clark, W., Logan, K., Luckin, R., Mee, A., \& Oliver, M. (2009). Beyond Web 2.0: Mapping the technology landscapes of young learners. Journal of Computer Assisted Learning, 25, 5669.

Comisión Lago Lanalhue. (2007). Informe: Lago Lanalhue. Cañete: Municipalidad de Cañete, Chile. 
Cuban, L. (2001). Oversold and underused: Computers in the classroom. Cambridge, MA: Harvard University Press.

Davis, B., \& Sumara, D. (2005). Complexity science and educational action research: toward a pragmatics of transformation. Educational Action Research, 13(3), 453-464.

Dohn, N. B. (2009). Affordances revisited: Articulating a Merleau-Pontian view. Computer Supported Learning, 4, 151-170.

Eames, C., Cowie, B., and Bolstad, R. (2008). An evaluation of characteristics of environmental education practice in New Zealand schools. Environmental Education Research, 14(1), 3551.

Engeström, Y. (1987). Learning by expanding: An activity-theoretical approach to developmental research. Helsinki: Orienta-Konsultit.

Engeström, Y. (2001). Expansive learning at work: Toward an activity theoretical reconceptualization. Journal of Education and Work, 14(1), 133-156.

Etchepare, M. S., \& Furet, L. R. (2008). Propuesta de un plan de descontaminación para un lago eutroficado. Caso de estudio: Lago Lanalhue. Unpublished Tesis de Magíster, Universidad del Desarrollo, Santiago, Chile.

Falk, J. H., \& Dierking, L. D. (2002). Lessons without limit. Boston: AltaMira Press.

Fauville, G., Lantz-Andersson, A., \& Säljö, R. (2014). ICT tools in environmental education: reviewing two newcomers to schools. Environmental Education Research, 20(2), 248-283.

Fien, J., \& Tilbury, D. (2002). The global challenge of sustainability. In D. Tilbury, R. B. Stevenson, J. Fien \& D. Schreuder (Eds.), Education and Sustainability: Responding to the global challenge (pp. 1-12). Gland, Switzerland: IUCN.

Galbraith, M. W. (1990). The nature of community and adult education. In M. W. Galbraith (Ed.), Education through community organizations (Vol. 47, pp. 3-11). San Francisco: Jossey-Bass.

Hofreiter, T., Monroe, M. C., \& Stein, T. V. (2007). Teaching and evaluating critical thinking in an environmental context. Applied Environmental education and communication, 6(2), 149157.

Huckle, J. (1991). Education for sustainability: Assessing pathways to the future. Australian Journal of Environmental Education, 7, 43-62.

Huckle, J. (1993). Chapter 3: Environmental education and sustainability: A view from critical theory. In J. Fien (Ed.), Environmental education: a pathway to sustainability (pp. 43-68): Deakin University.

Huckle, J., \& Sterling, S. (1996). Education for sustainability. London: Earthscan Publications. Jensen, B. B., \& Schnack, K. (1997). The action competence approach in environmental education. Environmental Education Research, 3(2), 163-178.

Jensen, B. B. (2002). Knowledge, action and pro-environmental behaviour. Environmental Education Research, 8(3), 325-334. 
Jorg, T. (2000). About the unexpected: complexity of learning based on reciprocity and human agency. Chaos and complexity theory: Special interest newsletter. Retrieved 8 June, 2009, from http://www.udel.edu/aeracc/library/Fall00.htm

Kollmuss, A., \& Agyeman, J. (2002). Mind the gap: Why do people act environmentally and what are the barriers to pro-environmental behaviour? Environmental Education Research, 8(3), 239-260.

Kompf, M. (2005). Information and communication technology (ICT) and the seduction of knowledge, teaching, and learning: what lies ahead for education. Curriculum Inquiry, 35(2), 213-233.

Krasny, M. E., \& Roth, W.-M. (2010). Environmental education for social ecological system resilience: A perspective from activity theory. Environmental Education Research, 16(5), 545-558.

La Pelle, N. (2004). Simplifying qualitative data analysis using general purpose software tools. Field Methods, 16(1), 85-108.

Lanalhue Sustentable. (2011). Lanalhue sustentable: El luchecillo. Retrieved from http://lanalhuesustentable.cl/post.php?id=26

Leadbetter, J. (2005). Activity theory as a conceptual framework and analytical tool within the practice of educational psychology. Educational \& Child Psychology, 22(1), 18-28.

Maturana, H. R., \& Varela, F. J. (1980). Autopoiesis and cognition: The realization of the living. Boston, PA/Dordrecht: Reidel.

McConnell, C. (1997). Community education: definitions, methods, paradigms. In C. McConnell (Ed.), Community education: The making of an empowering profession (2nd ed.). Edinburgh: Scottish Community Education Council.

McNair, S. (2006). ICT in non-formal and adult education: Reflections on the roundtable. In OECD (Ed.), ICT and learning: Supporting out-of-school youth and adults (pp. 151-164). Paris: OECD.

Menzel, S., \& Bögeholz, S. (2008). The loss of biodiversity as a challenge for sustainable development: How do pupils in Chile and Germany perceive resource dilemmas? Research in Science Education, 39, 429-447.

Ministerio de Planificación (MIDEPLAN). (2010). Situación de pobreza a nivel de personas, según provincia. Pobreza, CASEN 2006. Retrieved 8 November, 2010, from http://www.mideplan.cl/casen/Estadisticas/pobreza.html

Morrison, K. (2002). School leadership and complexity theory. London: RoutledgeFalmer.

Myers, N., \& Kent, J. (2005). The new atlas of planet management. Berkeley: University of California Press.

Nicolaou, C., Korfiatis, K., Evagorou, M., \& Constantinou, C. (2009). Development of decisionmaking skills and environmental concern through computer-based, scaffolded learning activities. Environmental Education Research, 15(1), 39-54. 
Nomura, K. (2004). Utilization of IT/ICT for environmental education: World school network. Retrieved 12 May, 2009, from http://www.iges.or.jp/APEIS/RISPO/inventory/db/pdf/0122.pdf

Organisation for Economic Co-operation and Development (OECD). (2006). ICT and learning: Supporting out-of-school youth and adults. Paris: OECD.

Orr, D. (1992). Ecological literacy: Education and the transition to a postmodern world. New York: State University of New York.

Orr, D. (2004). Earth in mind: On education, environment, and the human prospect (10th anniversary ed.). Washington: Island Press.

Orr, D. (2014). Systems Thinking and the Future of Cities. Solutions, 5(1), 54-61. Retrieved from http://www.resilience.org/stories/2014-05-30/systems-thinking-and-the-future-of-cities

Owston, R. D. (1997). The world wide web: A technology to enhance teaching and learning? Educational Researcher, 26(2), 27-33.

Pachler, N., Bachmair, B., \& Cook, J. (2010). Mobile Learning: Structures, agency, practices. Boston, MA: Springer US.

Pachler, N., \& Daly, C. (2009). Narrative and learning with Web 2.0 technologies: towards a research agenda. Journal of Computer Assisted Learning, 25, 6-18.

Parra, O., Valdovinos, C., Urrutia, R., Cisternas, M., Habit, E., \& Mardones, M. (2003). Caracterización y tendencias tróficas de cinco lagos costeros de Chile central. Limnetica, 22(1-2), 51-83.

Pauchard, A., Smith-Ramírez, C., \& Ortiz, J. C. (2006). Informe final estudio de diagnóstico del potencial de conservación de la biodiversidad de la empresa Forestal Mininco en la cordillera de Nahuelbuta. Concepción, Chile: Universidad de Concepción \& Fundación Senda Darwin.

Phelps, R., Maddison, C., Skamp, K., \& Braithwaite, R. (2008). Creating web-based environmental education resources through community and university partnerships. Australian Journal of Teacher Education, 33(3), 44-60.

Pont, B., \& Sweet, R. (2006). Adult learning and ICT: How to respond to the diversity of needs. In OECD (Ed.), ICT and learning: Supporting out-of-school youth and adults. Paris: OECD.

Räthzel, N., \& Uzzell, D. (2009). Transformative environmental education: A collective rehearsal for reality. Environmental Education Research, 15(3), 263-277.

Selwyn, N. (2006). ICT in adult education: Defining the territory. In OECD (Ed.), ICT and learning: Supporting out-of-school youth and adults. Paris: OECD.

Smith-Ramírez, C. (2004). The Chilean coastal range: A vanishing center of biodiversity and endemism in South American temperate rainforests. Biodiversity and Conservation, 13, 373-393.

Somekh, B. (2007). Pedagogy and learning with ICT: Researching the art of innovation. New York: Routledge 
Sterling, S. (2001). Sustainable education: Re-visioning learning and change. Bristol, UK: Green Books.

Sterling, S. (2005). Linking thinking, education and learning: An introduction. In W. Scotland (Ed.), Linking Thinking: New perspectives on thinking and learning for sustainability (Vol. 1). Surrey, UK: WWF-UK, Panda House.

Sumara, D., \& Davis, B. (1997). Enactivist theory and community learning: Toward a complexified understanding of action research. Educational Action Research, 5(3), 403422.

Thompson, J. (2002). Community education and neighbourhood (Vol. 1). Nottingham, UK: NIACE.

Tight, M. (2002). Key concepts in adult education and training (2nd ed.). London: RoutledgeFalmer.

Tilbury, D. (1995). Environmental education for sustainability: Defining the new focus of environmental education in the 1990s. Environmental Education Research, 1(2), 195-212.

Tilbury, D., \& Wortman, D. (2008). How is community education contributing to sustainability in practice? Applied Environmental Education and Communication, 7(3), 83-93.

United Nations Conference on Environment and Development (UNCED). (1992). Agenda 21: Chapter 36. Agenda 21. Retrieved 3 August, 2008, from http://www.un.org/esa/sustdev/documents/agenda21/english/agenda21chapter36.htm

United Nations Educational, Scientific and Cultural Organization (UNESCO). (2003). World heritage in young hands. The World Heritage Newsletter, 39(April-May), p. 3.

Vrasidas, C., Zembylas, M., Evagorou, L., Avraamidou, L., \& Aravi, C. (2007). ICT as a tool for environmental education, peace, and reconciliation. Education Media International, 44(2), 129-140.

Wallace, R. M. (2004). A framework for understanding teaching with the Internet. American Educational Research Journal, 41(2), 447-488.

Warner, A., Eames, C., \& Irving, R. (2014). Using social media to reinforce environmental learning and action-taking for school students (Unpublished manuscript). International Electronic Journal of Environmental Education, 4(2), 83-96.

Webb, M. E. (2002). Pedagogical reasoning: Issues and solutions for the teaching and learning of ICT in secondary schools. Education and Information Technologies, 7(3), 237-255.

Webb, M. E. (2005). Affordances of ICT in science learning: Implications for an integrated pedagogy. International Journal of Science Education, 27(6), 705-735.

Windschitl, M. (1998). The www and classroom research: What path should we take? Educational Researcher, 27(1), 28-33.

Woo, H. L. (2009). Designing multimedia learning environments using animated pedagogical agents: Factors and issues. Journal of Computer Assisted Learning, 25, 203-218. 
World Wide Fund for Nature (WWF). (1999). A biodiversity vision for the Valdivian temperate rain forest ecoregion of Chile and Argentina. Valdivia: WWF Chile.

Zachariou, A., \& Symeou, L. (2008). The local community as a means for promoting education for sustainable development. Applied Environmental Education and Communication, 7(4), 129-143.

$--$

Cite as (online first citation):

Aguayo, C., \& Eames, C. (2017). Promoting community socio-ecological sustainability through technology: A case study from Chile. International Review of Education.

https://doi.org/10.1007/s11159-017-9685-7

Published Online: 22 October 2017 